\title{
Lecturers' Perceptions about E-Learning on the Development of the Indonesian Qualifications Framework Curriculum
}

\author{
Fikri Aulia $^{1}$, Dinn Wahyudin ${ }^{1}$, Rusman $^{1}$ \\ \{fikri.aulia@student.upi.edu ${ }^{1}$,dinn_wahyudin@upi.edu ${ }^{2}$, rusman@upi.edu $^{2}$ \} \\ Universitas Pendidikan Indonesia, Indonesia ${ }^{1}$
}

\begin{abstract}
This research is to describe and analyze curriculum planning for the Indonesian Qualifications Framework in terms of best practices in improving the quality of learning through e-learning. The type of research conducted by the author is a field researcher who uses a mixed type of research. Mixed methods are used to describe the complexity of a problem that cannot be solved by just one method. The application of the Indonesian Qualification Framework Curriculum at Higher Education is very necessary because it can increase the potential of students to become broad-minded agents and have skills that are in accordance with the criteria needed in society, including internalization and accumulation of knowledge, skills, attitudes, and competencies achieved through the educational process structured and covers certain fields of knowledge or expertise or through work.
\end{abstract}

Keywords: Curriculum Development, Indonesia Qualification Framework, E-learning

\section{Introduction}

Implementation of Indonesia Qualification Framework Curriculum in Higher Education is very necessary because it can increase the potential of students to become a broad-minded agent and have skills that are in accordance with the criteria needed in the community [1]-[7]. In addition, Indonesia Qualification Framework Curriculum system makes it easier for universities to determine the ultimate goal as a result of learning achievements that have been taught. Thus, the implementation of Indonesia Qualification Framework Curriculum makes the students more contribute in various ways.

The Indonesia Qualification Framework Curriculum is a form of curriculum development in universities. Curriculum Development has a more comprehensive meaning that includes planning, implementation, and evaluation. The curriculum planning stage is a preliminary process for curriculum developers to make decisions and actions to create a curriculum design that contains four main curriculum components: objectives, content, activities, teaching, and evaluation. And the implementation of the curriculum is the stage of translation of curriculum design into action. While the evaluation stage of the curriculum is the final stage of the curriculum development process where the results of curriculum implementation assessed effectiveness and efficiency, both related to educational products and the curriculum itself. the term curriculum development as interpretation as the second phase of the curriculum development process, the process of a concept to a curriculum document that is ready to be implemented and evaluates [8]-[12]. 
Curriculum development in this study was carried out in the preservice education at the university. The university must facilitate prospective teachers in the learning process. Lecturers as instructors at the university must be able to identify the advantages of each individual teacher candidate. In addition, lecturers must also strive to expand the network of professional teachers so as to create a more comprehensive field experience. With these efforts it is expected that profits will occur for universities as preservice education providers and that university programs can be disseminated to the public. Teacher experience must be disseminated to community partners, this aims to provide positive benefits for partners involved in preservice education programs.[13]-[17].

Efforts in producing competent graduates according to Indonesia Qualification Framework Curriculum, a private institute of education compile the courses in accordance with the vision and mission that have been made, provide a reliable lecturer and provide adequate facilities, using of E-Learning, with E-Learning process teaching and learning will be more effective[18][25]. From the author's observation of the private institutions of education using Indonesia Qualification Framework Curriculum, students are better prepared to be graduates who are responsive to the competition. Not only excels in academics but also has soft skills as a provision to compete in the world of work.

The problem of this study the authors focus on the planning of curriculum development in strengthening learning outcome, graduate quality and institute of education profile quality in private universities using e-learning.

\section{Method}

Type of research conducted by the field research using a mixed method. mixed method is a form that utilizes the power of qualitative and quantitative research methods. Mixed methods are used to describe the complexity of a problem that cannot be solved by just one method.

This study chose a location in Central Java. The object is Curriculum Development in education science program and mathematics education program at education and teacher training faculty Universitas pancasakti tegal. The categories of data sources are institutions, events, documents, and people. The category of institutional data sources includes agencies, institutions and organizational units related to curriculum development policies. The process of collecting data in this study the author goes through the orientation and overview stages, the exploration phase, and the member check stage

\section{Result and Discussion}

The implementation of Indonesia Qualification Framework through 8 stages there is a determination of Graduation Profile, Formulating Learning Outcomes (LO), Formulating Competence of Study Materials, LO Mapping of Study Materials, Packaging Subject, Preparation of Curriculum Framework, Lecturing Plan Lecturing. Learning Outcomes are the internalization and accumulation of knowledge, skills, attitudes, and competencies achieved through a structured education process and cover a particular field of knowledge/expertise or through work experience.

Referring to the coverage of the general description and description of the 6 and 7 qualification levels in the attachment of Presidential Regulation No. 8 year 2012 and the profile 
of teachers adapted to the unique characteristics of the teaching profession are: the subject of service is human, the unique individual who develops; is essentially no different from educators, the subject of services that have various potentials; professional decisions are made in dynamic transactional situations, the following is outlined in the General Description and Learning Outcome of institute of education graduates.

Basically, the general description is a breakdown of a number of competencies that must be built on the graduate profile of learners from each institute of education with characterized and oriented aspects of moral, personality, social, and professional values. Learning outcomes are expected to know, at the end of a module and the how that learning will be demonstrated. Thus, the Learning Outcome presented is more characterized by a general description that describes the generic profile of teachers with the achievement of general learning outcomes in the Institute of education. Detailed study The graduate profile and learning outcome remains in line with the characteristics and scientific study of each study program at the Institute of education.

Table 1. The Curriculum Development Focus

\begin{tabular}{|c|c|}
\hline Curriculum Development Focus & Activities \\
\hline Reconstruction of the curriculum & $\begin{array}{l}\text { 1. Workshop on IQF-based curriculum development } \\
\text { and market-oriented needs } \\
\text { 2. Evaluation and reconstruction of the curriculum }\end{array}$ \\
\hline Improving the quality of learning & $\begin{array}{l}\text { 1. Multimedia-based learning and e-learning training } \\
\text { 2. Learning design workshops and preparation of } \\
\text { learning tools } \\
\text { 3. Monitoring and evaluation of the learning process }\end{array}$ \\
\hline $\begin{array}{l}\text { Institutionalization of curriculum } \\
\text { studies }\end{array}$ & $\begin{array}{l}\text { 1. Facilitate the participation of lecturers in a similar } \\
\text { study program consortium between universities } \\
\text { 2. Aligning content and weight of core curriculum } \\
\text { courses with institutional curriculum or local } \\
\text { content. }\end{array}$ \\
\hline
\end{tabular}

The focus of curriculum development in this research is on curriculum reconstruction by conducting curriculum-based curriculum development workshops and based on market needs. the second is to improve the quality of learning by using e-learning in learning and designing learning training. The next focus is to sharpen the learning curriculum by facilitating lecturers with a consortium program with universities, developing a core curriculum for lectures with local learning materials. In the development of the higher education curriculum emphasizes on the preparation of material content and learning materials, besides that it is necessary to pay attention to the way of learning. Curriculum planning also contains graduate competency standards that are structured in key competencies, supporting competencies to achieve goals, mission implementation, and realization of the study program vision. The curriculum contains courses that support the achievement of graduate competencies and provide flexibility for students to broaden their knowledge and deepen their skills in accordance with their interests which are equipped with descriptions, syllabi, learning, and evaluation plans. [26].

The designed curriculum must have conformity with the objectives, fields of study and material so that it can develop personality, hard skills, soft skills and be able to solve existing problems. The implementation of learning can fulfill many functions that are beneficial for students with using the e-learning such as: provide knowledge about learning objectives, motivate students, presenting information, stimulate discussion, directing student activity, exercises, strengthen learning or reinforcement, provide simulation experience. 


\section{Conclusions}

Developed with the Indonesian National Qualification Framework (KKNI) that defines the competency of graduates into the minimum learning achievement. The formulation of graduate competence involves relevant expert groups, professional associations, relevant government agencies/graduate users. Curriculum evaluation is a consideration-making process based on a set of agreed-upon and accountable criteria for making decisions about the curriculum. The curriculum evaluation aims to obtain accurate information as input to make decisions in the design, implementation and learning outcomes. So in the evaluation should pay attention: (1) rational, real needs in the field; (2) specification, clear and special meaning; (3) benefits, that is useful for learners; (4) effectiveness means to be successful; (5) conditions ie prerequisites in the implementation of the curriculum; (6) practical, it means supporting the implementation of the curriculum; (7) dissemination means improvement of the next curriculum. The curriculum evaluation is conducted from a competency-based curriculum that contains the main competencies, support competencies, and other competencies.

Acknowledgments. I would like to thank the Institute of Education Fund Management (BUDIDN and LPDP) who has given full support so that this paper can be realized.

\section{Referensi}

[1] Bagyo Y. Moeliodihardjo, M. Santoso, I. B. A. Putra, S. F. Abdurrahman, M. Slowey, A. Doolette, A. Bateman, and A. Agustina, "Support To the Development of the Indonesian Qualifications Framework ( Acdp - 024 ),” PT. Trans Intra Asia, no. November, pp. 150-162, 2015.

[2] D. Setyawarno and Z. K. Prasetyo, "Development Of Indonesian Qualification Framework (IQF) Level 6 Of Physics Education,” no. May, pp. 16-17, 2016.

[3] C. R. Prihantoro, "Implementation of National Qualification Framework-Based Curriculum in Universities ( Content Analysis Study on Machine Drawing Lecture )," vol. 97, no. 2, pp. 317328.

[4] U. N. Yogyakarta, "Evaluation of Indonesian National Qualification Framework-Based Learning Process in Faculty of Education Universitas Negeri Yogyakarta," vol. 66, no. Yicemap, pp. 260$265,2017$.

[5] B. A. Hutabarat, "Evaluation of Indonesian National Policy Framework on Higher Education," vol. 8, no. 20, pp. 35-40, 2017.

[6] D. Setiawan, "Validator' s View in the Implementation of Curriculum Oriented on the Indonesia National Qualification Framework ( KKNI ) Social Science Faculty, State University of Medan ( Unimed ), Medan, Indonesia," vol. 22, no. 12, pp. 66-72, 2017.

[7] S. Susilo, "Curriculum of EFL Teacher Education And Indonesian Qualification Framework : A Blip of the Future Direction," Din. Ilmu, vol. 15, no. 1, pp. 11-24, 2015.

[8] M. Print, Curriculum Development, and Design. Sydney: Allen \& Miller, 1993.

[9] P. F. Oliva, Developing the Curriculum. New York: Hirper Collins Publisher, 1992.

[10] X. Tian and B. Martin, "Curriculum design, development and implementation in a transnational higher education context," J. Appl. Res. High. Educ., vol. 6, no. 2, pp. 190-204, 2014.

[11] L. Ali, "The Design of Curriculum, Assessment, and Evaluation in Higher Education with Constructive Alignment," J. Educ. e-Learning Res., vol. 5, no. 1, pp. 72-78, 2018.

[12] S. P. Fraser, A. M. Bosanquet, T. Need, C. Scale, J. T. Dillon, G. O’Neil, K. Engaging, S. Barradell, S. Barrie, T. Peseta, R. Barnett, G. Parry, and K. Coate, Curriculum Design in Higher Education: Theory To Practice, vol. 16, no. 3. 2018.

[13] I. Abdulhak, A. Djohar, and D. Wahyudin, "The Development of Hybrid Learning Curriculum Model for Improving Teachers Competencies in Teacher Education Institutions in Indonesia and South Korea," vol. 3, no. 1, pp. 31-35, 2018. 
[14] D. Wahyudin, D. Rusmono, Y. Rahmawati, and U. P. Indonesia, "Teaching Philosophy of Selected Teacher Education Institutions," vol. 5, no. 4, pp. 67-78, 2017.

[15] E. Marquis, Z. Haqqee, S. Kirby, A. Liu, V. Puri, R. Cockcroft, L. Goff, and K. Knorr, Connecting students and staff for teaching and learning inquiry: The McMaster Student Partners Programme. 2017.

[16] S. Bohlinger, "Competences as the core element of the European Qualifications Framework," Eur. J. Vocat. Train., no. 42/43, pp. 96-112, 2008.

[17] C. Oksiutycz, A. \& Azionya, "Using Action Research for Curriculum Development and Improving the Learning Experience: a Case Study," South African J. High. Educ., vol. 31, no. 3, pp. 193-208, 2017.

[18] C. Costa, H. Alvelos, and L. Teixeira, "The Use of Moodle e-learning Platform: A Study in a Portuguese University,” Procedia Technol., vol. 5, pp. 334-343, 2012.

[19] D. Benta, G. Bologa, S. Dzitac, and I. Dzitac, "University level learning and teaching via elearning platforms," Procedia Comput. Sci., vol. 55, no. Itqm, pp. 1366-1373, 2015.

[20] N. Cavus, "Distance Learning and Learning Management Systems," Procedia - Soc. Behav. Sci., vol. 191, pp. 872-877, 2015.

[21] A. Simo, C. Barbulescu, and S. Kilyeni, "Current Practices in E-learning: A Case Study for Electrical Power Engineering in Higher Education," Procedia - Soc. Behav. Sci., vol. 191, pp. 605-610, 2015.

[22] J. Truskolaska, M. Łuka, N. Toruj, K. Wrona, and P. Smagowska, "E-learning at the Polish University in the Opinion of Students," Procedia - Soc. Behav. Sci., vol. 174, pp. 3494-3499, 2015.

[23] M. T. Banday, M. Ahmed, and T. R. Jan, "Applications of e-Learning in Engineering Education: A Case Study,” Procedia - Soc. Behav. Sci., vol. 123, pp. 406-413, 2014.

[24] D. Benta, G. Bologa, and I. Dzitac, "E-learning platforms in higher education. Case study," Procedia Comput. Sci., vol. 31, pp. 1170-1176, 2014.

[25] G. C. Oproiu, "A Study about Using E-learning Platform (Moodle) in University Teaching Process," Procedia - Soc. Behav. Sci., vol. 180, no. November 2014, pp. 426-432, 2015.

[26] B. Lapau, "The Application of Indonesian Qualification Framework In Several Studies on Occupational Health,” no. 4, pp. 19-22, 2016. 